\title{
ANOMIE, ALIENATION AND THE EVALUATION OF SOCIAL STRUCTURES*
}

\author{
Christopher Bagley \\ Sociological Research Unit, London School of Economics
}

The purpose of this article is to discuss and analyse the use of the concepts of anomie, alienation and egoism in recent sociological literature; to relate these concepts to their original use by Durkheim and Marx; and to examine the extent to which these concepts may be used to show a connection between sociology and cthics - that is, the extent to which it is legitimate to derive an evaluation of social structures from a description of them.

Robert Merton's essay Social Structure and Anomi. ${ }^{1}$ has had widespread influence on both theoretical and empirical studies in the field of social deviance. Clinard and his co-authors summarise the work carried out under the influence of Merton. As Clinard points out, ${ }^{2}$ Merton's idea of anomie is derived, with certain modifications, from Durkheim.

Durkheim's central thesis in relation to anomie is the idea that no living being can be happy or even exist unless his needs are sufficiently proportioned to his means. Durkheim relates the individual's needs to his biological nature, an interpretation that Merton avoids.

If nothing external can restrain this capacity for need fulfilment it can only be a source of torment to itself,

says Durkheim.

Unlimited desires are insatiable by definition and insatiability is rightly considered a sign of morbidity. Being unlimited, they constantly and infinitely surpass the means at their command...to pursue a goal which is by definition unattainable is to condemn oneself to a state of perpetual unhappiness. 3

Merton uses the anomie theory in analysing social structure, and arrives at the:

central hypothesis that a'jerrant behaviour ... is ... a symptom of dissociation betwcen culturally prescribed aspirations and socially structured iveries for realizing these aspirations.

From this hypothesis Merton develof: a paradigm of sccial deviance, according to the actor's acceptance, or rejectior of cultural goals, and institutionalized means for reaching these goals. 4

*abstracted from an M.A. thesis, University of Essex, 1966.

$$
\text { K.J.S. III, } 3 \quad 110 \quad \text { Summer, } 1967
$$


In some ways lierton does justice to Durkheim's concept to anomie, but in some ways strays from it. His analysis of deviance describes states of social structure which are in conceptual accord with his original hypothesis, but yet cannot be related to Durkheim's concept of anomie. The Principal example of this type of deviance is that arising from the blocking of aspirational goals by elements of the social structure - the kind of deviance analysed by Cohen, 5 and Cloward and Ohlin. 6 In this case, lower class individuals resort to deviant behaviour (delinquency) because of their inability to reach the middle class goals towards which processes of rational communication motivate them.

It seems much more profitable, however, to derive this process from Marx's concept of alienation, rather than Durkheim's anomie, since the elements of "unlimited aspirations" and "lack of normative constraint" seem singularly lacking here. The lower class youth's aspirations - the achievement of middle class material standards - are not unlimited, but are moderate, and clearly defined. And far from lacking in constraint, he is over-constrained, by the social structure which prevents his reaching his goals. This type of deviance, in fact, appears to be the analytical opposite of Durkheim's anomie. It arises from the blocking of aspirations by aspects of social structure; Durkheim's deviance arises from the excessive achievement of aspiration, because of the lack of normative constraint.

Merton's typology of deviance, then, appears to contain deviance of both the anomic and the alienative type, but is presented under the general heading of anomie. In fact, the anomic deviance described by lierton - the finding of novel, and perhaps illegal ways of bridging the dissociation of aspirations and institutionalized means - appears to be part of the process of anomie, and is not analytically distinct from it. The deviant reactions to alienation, however, are in fact analytically distinct from alienation, and may take a variety of forms. This point will be developed below.

The terms "alienation" and "anomie" appear to have been used in recent years with some ambiguity and confusion - as interchangeable or interconnected concepts, rather than as analytically separate ideas. Further confusion has been added by the use - albeit highly successful - by Gibbs and Martin 7 of the Durkheimian concept of egoism, rather than anomie, as the crucial sociological variable in explaining suicide.

\section{The Concept of Egoism}

Discussing suicide resulting from "egoism", Durkheim suggests that:

Egoistic suicide results from the fact that society is not sufficiently integrated at all points to keep all its members linder its control. If it increases inordinantly, therefore, it is because the state on which it depends has itself excessively expanded; it is because society, weak and disturbed, lets too many persons escape too completely from its influence. Thus, 
the only remedy for the $i 11$ is to restore enough consistency to social groups for them to obtain a firmer grip on the individual, and for him to feel himself bound to them. He must feel himself more solidary with a collective existence which precedes him in time, which survives him, and which encompasses him at all points. 8

Gibbs and Martin, in an empirical monograph on suicide, ${ }^{9}$ begin by reformulating Durkheim's concept of anomie into a series of testable propositions. In attempting to operationalise both egoism and anomie as predictors of suicide, they are forced to the conclusion that the key to both these concepts is one derived from egoism - the degree of social or status integration in a society. They work through a series of heuristic postulates to arrive at the basis proposition:

The suicide rate of a population varies inversely with the degree of status integration in that population.

Thus Durkhei.l's two predictors of suicide rates - anomie and egoism are subsumed under a single basic proposition. What is important atout this proposition is the way in which it can be put to quantifiable examination, using crnsus data. The number of people in a society occupying incompatible statuses can, in this way, be measured. Gibbs and Martin verify their propositions on a variety of census data, ranging from internal correlation studies of English, Belgian, nineteenth century, American and modern West Bengal data, to crosscultural studies. The number of high correlations between the measure of social integration, and suicide rates, is nothing short of astonishing. Anyone who has used the correlation technique with census data will know just how difficult significant associations are to obtain.

\section{The Concept of Anomie}

Durkheim's use of this concept has been indicated above. Durkheim concedes that egoism and anomie are closely related, but does not make the relationship clearly explicit:

Anomy indeed springs from the lack of collective forces at certain points in society; that is, of groups established for the regulation of social life. Anomy therefore partially results from the same state of disaggregation from which the egcistic current also springs. But this identical cause produces different effects, depending on its point of incidence and whether it influsnces active and practical functions, or functions that are representative. 10

\section{The Concept of Alienation}

Horowitz has recently attempted a clarification of the use of the term alienation about which, he points out, there is "an incredible degree 
of confusion."11 In the tradition of linguistic philosophy, Horowitz shows how parts of the "meaning" of one notion of alienation are dragged, by a semantic accident, to another use. At the same time, the purveyors of the concept (e.g. modern sociologists) may be unaware of the conceptual confusion which surrounds alienation.

Horowitz delineates six distinct uses of alienation: firstly, Hegel argue that alienation occurred in the separation of the object of cognition from the man of consciousiess, tle philosopher; Feurbach saw alienation as an anthropological, or psychological problem, where one part of man is invested (properly) in the material world, and another part of himself is invested in the world of God - the projective, ideal world. Harx transferred the notion of alienation from the framework of philosophy to social structure, and insisted upon the soci!l scientific resolution of what had up to then been considered a netaphysical or humanistic dilemma. larx transferred alienation from "nan" to the economic sphere of social man, the factory.

From, in the fourth use of alienation, converted ilarx's "mode of production" into a. "mode of experience", while the Marxian proletarian labourer was neatly converted back into the Hegelian abstract person. A fifth use of alien-ition has been devcloped by sociologists as a psychological counterpart of anomie, with a shift of emphasis from separation to "lessness". A variety of "lessness" concepts are equated with alienation - powerlessness, nornlessness, meaninglessness. We shall discuss this problem extensively later on in the paper.

The final use of alienation is as an elevated psychological concept linked to the notion of ideology. This in turn is fused with the notion of how intellectuals view their roles in the social world.

In his conclusions about the uses of alienation, Horowitz points out that in effect the diffuse uses of alienation spring from the influence of iarx, in setting alienation in the social world. Marx saw alienation as the loss of the self in the social conditions imposed by a dominant class. But:

... once Marx opened this Pandora's box of the social and cross-cultural. Iocale of alienation, it was just a matter of time before others yould see alienation of different social sectors from thore liarx had dealt with.

In the present paper we shall try to develop a notion of alienation which has a close conceptual. relation to ilarx's original use of the term, centering round the idea of alienation as estrangement from the self, in the context of society.

Marx's alienation is seen as a denial of the basic personality of man - his social personality - because of the dichotomy between the social relations which are natural to men, and the means of production, which are not social, but are divorced from man by the class division between owners 
and workers.

What constitutes the alienation of labour?" asks Marx:

First, that the work is external to the worker, that it is not part of his nature; and that, consequently, he does not fulfil himself in his work but denies himself, has a feeling of misery rather than well being, does not develop freely his mental and physical energies but is physically exhausted and mentally debased... 12

Marx derived alienation from an analysis of man's economic activity. But since, in ilarx's view, the rest of society's relations are based on this economic activity, the alicratiion of man extends to many spheres of life, which are not principlly economic. Harx, as Popper13 clearly shows, developed an implicit moral theory which criticised the lack of freedom of the alienated man in all areas of society.

Blauner 14 traces the origins of the concept of alienation in the work of Hegel and Marx through to its modern use, and concludes:

Domination, futility, isolation, and discontent are each aspects of experience that have been identified as elements of the general condition of alienation, a leading perspective in modern sociological thought.

The key to alienation Blauner sees as powerlessness. This idea of powerlessness is a different use from that of the anomie theorists; it refers not to normlessness, but to a lcck of porver, of means, to find fulfilment of the self.

Alienation, then, is a state of powerlessness, a lork of freedom to grow to the full stature of the self. In the context of social structure, we take alienation to mean a dichotomy between the fulfilment of man's basic personality, and the socially availaile means for fulfilment of personality. It is a denial, by some aspects of social structure, of the freedom of man to fulfil some of his basic needs.

In arriving at this definition of alienation, we would point out two assumptions which are made in this assay. Firstly, contrary to Merton, and following Durkheim, man has a basic set of bionogical and personality orientations (or 'nceds' in Marx's term) rinich are not the product of the society l:e lives in; and secondly, following the Aristotelian line of argument, thicugh viarx, and Iurkheim, the most natural fulfilment of man's basic personality is a social one:

... it is evident that a city is a natural production, and that man is naturally a political animal, and that whosoever is naturally and not accidentally unfit for society, must either be inferior or superior to man: ... he who first founded civil society was the cause of the greatest good; for as by the com- 
pletion of it man is the most excellent of all living

beings, so without law and justice he would be the worst

of al1 ... 16

The first assumption does not, of course, fall into the fallacy, which Alpert 17 has pointed to, of explaining the variable of social behaviour by means of a constant-fixed psycho-biological factor. It is essential to our argument that the crucial variable in the outcome of personality is social structure.

The Connections Between Anomie, Alienation and Egoism

These three concepts and the relations between them have been used by modern sociologists in a variety of ways.

Clinard, in an essay on the exposition, criticisms and applications of Herton's theory of "social structure and anomie" delineates the use of alienation as the subjective aspect of anomie:

The destinction is not always clear, but the alienated individual is considered to be marginal, normless and isolated.

Alienation is similar to what others, such as Srole, ieier and Bell, have referred to as 'anomie'. 18

Parsons, Bales and Shils have used alienation in the study of deviance in a rather similar sense, involving the actor's "need to express alienation from the normative pattern". 19 The authors point out that their model, though independently derived, is essentially the same as that put forward by Merton for the analysis of social structure and anomie. Alienation in this sense is ego's reaction in the face of an "anomic" situation - a dissociation between culturally prescribed aspirations and socially structured avenues for realizing these aspirations.

Nettler, in attempting a measure of alienation, acknowledges the origin of this concept in the writing of Hegel and Marx, but arrives at the conclusion:

Alienation and anomie are undoubtedly correlated; at least it is diffirult to conceive any notable degree of anomie that would r.ot result in alienation... 20

Mizruchi also acknowledges the origin of alienation in the work of Marx, and anomie in that of Durkheiin, but concludes, following previous American writers on the subject, that anomie "includes elements of both meaninglessness and alienation".21 After an empirical study, however, he concludes that there are different types of anomie, lower class and upper class. The two types are differentiated by the different relation to opportunity structure of the two classes.

The uses of anomie and alienation by the American writers examined seem 
to imply that both concepts are closely related, alienation being either a psychological correlate of anomie, or its subjective aspect, or a subsidiary element of anomie.

Horton has presented a somewhat different view, seeing anomie and alienation as counter-concepts, describing essentially the same behaviour and discontents, but from polar opposite positions. Alienation is the critique of society of the political left; anomie the critique of the political right. The two concepts he seems to see as different perspectives of society, with different philosophical bases:

Alienation assumes an immanent interpretation of man and society; anomie a transcendent one. 22

Basically, however, Horton seems to take a position fairly similar to the American writers - that anomie and alienation are very close, if not identical concepts, describing:

essentially the same behaviour and discontents, but from polar opposite perspectives ... 23

We are now left with the task of relating alienation, anomie and egoism. Dohrenwend 24 distinguishes Durkheim's use of anomie and egoism by their relation to social norms, which, in Durkheim's sense, are equated with social pressures. Anomie arises because of lack of social norms; egoism arises because of a contrast between ego's norms and the collective norms. In its "simple" form, however, Dohrenwend suggests that anomie indicates not normlessness in society, but normative confusion, because of a conflict between value systems. Only in its "acute" state is anomie equated with a disintegration of value systems. The difficulty with this position is that it is difficult to see any difference between egoism and simple anomie, since both states represent uncertainty and unhappiness on the part of ego because of a lack of normative regulation in society. Acute anomie and egoism are not the same, but it is difficult to see how such an acute state can exist. Acute anomie cannot be a state of society, since, as Parsons has pointed out, 25 the notion of a society necessarily involves the notion of a community having a system of values which at least loosely integrates society. A group of actors who are completely without normative constraints on their conduct is presumably akin to the Hobbesian pre-society. The difficulty with this sort of society, of course, is that it has never existed outside Hobbes' deductive scheme. It is certainly not like any society considered by Durkheim. What in fact anomie seems to refer to is a lack of ethical precision in society about the conduct of individual roles a normative weakness of the collective life which allows different normative standards to conflict. It is difficult, now, to see any difference between the states of anomie and egoism. This conclusion is similar to that drawn by Gibbs and liartin, 26 who, in operationalising anomie and egoism found the two conceptually indistinct. These authors developed egoism as the significant predictor of suicide rates in sociology. Egoistic suicide, operationalised by its relation to the stability and durability of social relationships 
within a population, includes Durkheim's anomic suicide.

Johnson, 27 following a different line of argument, reaches a similar conclusion. The two precursors of suicide - lack of integration, preceding anomie, and lack of regulation preceding egoism - are in fact similar states. It follows that anomie and egoism are similar also. In fact, Durkheim seldom locates a high suicide area having either anomie or egoism. Johnson argues that two states coincide empirically. If anomie is present, egoism will be also.

Some writers have argued that alienation is the subjective aspect of anomie, but this interpretation seems to be based on a facile merging of the two concepts, which have distinct origins and meanings. A more realistic interpretation seems to be that egoism is the subjective state of anomie, anomie being the description of a state of social structure, and egoism of the psychological state of individuals in it.

The relation between anomie and alienation leads to a further proposition: anomie and alienation are conceptions of two different states of social structure. Alienation arises through the blocking of fundamental aspirations for the fulfilment of personality: goals are clearly perceived, but socially available means for the achievement of these goals are lacking. Anomie stands at the opposite end of this spectrum: goals are diffuse and unclear. Means of achievement, too, are diffuse, what ego lacks is normative guidance in the choice of both goals and means, and normative constraint to prevent a disjunction between motivated behaviour, and behaviour necessary for fulfilment of personality.

A third proposition arises: midway in tinis spectrum lies normality which is characterised by the normal society, which, in the Greek tradition, fosters the full development of the people within it.

Two analogies, taken from biology, may help in the understanding of these last two propositions. We have argued that social structure can be evaluated in three distinct ways: by the extent to which it is alienative, by the extent to which it fosters full develepment of personalities, and by the extent to which it fosters anomie, a kind of "excessive fulfilment". A man who is permanently undernourished is unfulfilled. A man who consistently overeats is in danger of nausea or physical corruption. Gluttony is an egoistic reaction. Malnutrition is not, but is a function of environment. Both malnutrition and gluttony are destructive of biological fulfilment. They are technically related, but analytically distinct states. In Mertonian terms, however, they might be considered as analytically similar in that both states represent a disjunction between biologically prescribed aspirations and the means of fulfilling those aspirations.

The second analogy is borrowed from Aristotle, and relates to the state of micturition. Normal micturition is a natural state, but both incontinence, and physiological impediments to normal micturition are pathological states. The two states are technically related, but have different 
aetiologies. In Aristotle's phrase, the egoistic man is "morally incontinent", and "does wrong, knowing it to be wrong, because he cannot control his passions".28 In Durkheimian terms, the "morally incontinent" man lacks the constraint of society in controlling his passions.

\section{Alienation and Anomie: Empirical Examples}

The present study arises from a brief theoretical proposition made in an empirical study of juvenile delinquency by the present writer. 29 This study computed correlations between social data and delinquency rates in twenty-two geographically similar English cities, and showed a significant correlation $(-0.6)$ between a measure of job opportunities and delinquency rates; and a significant correlation $(-0.58)$ between Youth Service provision and delinquency rates. Youth Service provision and job opportunities were not themselves correlated. A detailed study of the characteristics of the delinquents in one of the cities (Exeter) was made, and the conclusion drawn that delinquency rates became higher as occupational aspirations of young people were blocked, by lack of job opportunities. Provision of Youth Services tended to allay this trend to delinquency.

This phenomenon appears to be the analytic opposite of Durkheim's anomie, which is typified by an individual unregulated by stable norms of conduct, and with s: aingly limitless aspirations. The psychological result of this detachment from the integrated aspirations of a stable social group is various degrees of unhappiness leading, most drastically, to suicide. The links with the frustration-aggression hypothesis will be seen: frustration from unconstrained behaviour leads to goalless aggression, which leads to aggression against the self.

Delinquency resulting from the blocking of occupational aspirations is clearly not the result of anomie, but is the opposite of it. Goals the achievement of middle class material standards - are not diffuse, distant, or unclear, but are concrete and clearly perceivable. The avenue towards these goals is blocked through lack of job opportunity. The result of this frustration is anger, and externalised aggression. In many cases this may lead to delinquency: that is, the aggression if aimed at the apparent agents of frustration leading to an assault, by theft and vandalism upon the values and property of the middle class. This aggression, as in this example, is often group aggression, by collections of young men in the same community who experience similar frustrations. This is the type of delinquency described $\mathrm{ry}$ ?nhon, and Cloward and OhIin. 30

These young men are alienated from their goals. The political outcome, in classic larxian terms, is of revolutionary activity by an alienated working class. Downes, horvever, in a study of delinquent subcultures in East London suggests that any political reaction by youth in the situation of goal-deprivation might be of a quasi-fascist kind. 31

The example of anomie is that given by Mizruchi, and is a quotation 
from W. F. Whyte:

'One of the hazards of the kind of life we lead,' says a man now poised at the threshold of the top management of one of our largest corporations, 'is the loss of well-defined objectives. What is our purpose? What is the end? I was deeply a part of my job in the chemical division. Hy wife and I were deeply part of the community: I was contributing and was effective. Then they asked me to come to New York the V.I.P. in charge told me that by coming here I'd have a box seat in the Big Time. If his guess had been bad, it's a terrible waste. I hope the company isn't playing checkers with me. I don't know what contacts to keep alive. A sales manager knows he should keep his customer contacts, but in broad management philosophy you can't do this. You have to guess. ${ }^{7} \cdot 32$

In the case of anomie, the actor has no precise normative goal, or normative constraints upon his means of goal achievement. He has no stable reference group which will offer a normative guide to his actions. In evaluating the situations of his life, he stands alone, in egoism. His "deviant" actions are internally part of this anomic state. He is in that state in which:

the most blameworthy acts are so often absolved by success that the boundary between what is permitted and what is prohibited, what is just and unjust, has nothing fixed about it, but seems susceptible to almost arbitrary change by individuals. 33

The goal of the actor in anomie relates to "the state of infinite elevation," as Mizruchi puts it. In pursuing this goal, the actor seems free to choose a variety of means. In Mertonian terms, these choices often involve "deviant reactions". If we look at the problem in the light of Durkheim's analysis, however, these acts are not secondary, or external to anomie, but are part of the state of anomie, being "blameworthy acts" which are "so often absolved by success". The real externally deviant reaction to anomie seems to be a complete rejection of both means and goals, by a monastic withdrawal from life, or, alternatively, by suicide.

Alienation, on the other hand, seems to be an aspect of social structure that is analytically discrete from the deviant reactions that may follow it. Deviant reactions to alienation are external to alienation: that is, unlike anomie, the definition of alienation does not logically include deviant acts. The anomic individual who "accepts" his fate - both goals and means - is necessarily involved in deviant actions, which are part of the state of anomie. But the alienated individual - the humble worker, who does not seek alternative means to economic advancement, and does not rebel against his fate, by joining, for example, a trade union 
activity - who accepts both the goals and means allotted him by society, cannot be termed a deviant.

Our criticism of the Mertonian scheme of deviance now becomes apparent. Merton uses "anomie" as a single category embodying both the concept of alienation derived from Marx, and the concept of anomie derived from Durkheim. This cannot but lead to some confusion in classifying states of social structure which lead to deviance, and to a confusion in the use of the two terms alienation, and anomie.

\section{Alienation, Anomie and Social Structure}

We have argued, in the Durkheimian tradition, that the final variable in the outcome of social behaviour is not individual personality but social structure. The concepts of alienation and anomie are descriptions of two different aspects of social structure. The one describes that aspect of society by which the fulfilment of basic personality is blocked; the other describes that aspect of society by which the fulfilment of basic personality is denied by the lack of a normatively structured system of goals, and means of achievement of goals. Ego's reactions in the first case we posit as anger and frustration; in the second, bewilderment and confusion. In the first case anger is externalised, and may be directed against the agents of frustration; in the second, the direction of anger is confused, and may well be internalised, with resulting depression and suicide. Ego fails to find basic fulfilment;

To fill up the gap he feels inside himself, he seeks new sensations; he applies, to be sure, less ardour than the passionate temperament properly so-called, but he also wearies sooner and this weariness casts him back upon himself, thus re-inforcing his original melancholy. 33

\section{Marx and Durkheim}

The task remains of briefly relating the work of Marx and Durkheim on the historical emergence of alienation and anomie. In this respect, we cannot do better than rely on the excellent essay by Alvin Gouldner, which appears as an introduction to Durkheim's Socialism. As Gouldner points out, Durkheim was aware of Marx's work, and was not uninfluenced by it, and at times there is considerable congruence of their accounts of society. For example, Durkheim explicitly argues that the developing industrialism brings about specific changes in the consciousness of man.

The increasing division of labor is a normal development in modern industrial society. It does not naturally produce social disorganization, but does so only under certain conditions. The two most important of these are, first, there anomie prevails in the economy ... The second is where there is a 'forced division of labour' that is, where people are constrained to take up positions in the division of labor at variance with their natural talents. 34 
This "forced division of labour" is, of course, the condition leading to what Marx called alienation. Gouldner argues that Durkheim's work, after The Division of Labour could have taken two directions - the analysis of anomie in society, or the analysis of "the forced division of labour." He followed the former path because he was still deeply committed to Comteian assumptions, believing that some degree of moral consensus is indispensable to social solidarity. However, the implicit assumption remains that the forced division of labour, delineated in Durkheim's early work, engenders tensions because people have been forced into occupations at variance with their natural talents. This condition is, of course, the opposite of the anomic division of labour. Had Durkheim continued his analysis of the forced division of labour he would, as Gouldner says, have been constrained into a concern with systems of stratification and power relations, in short into a greater convergence with lilarxism.

\section{FOOTNOTES}

1. Chapter 4 of Social Theory and Social Structure, 1957,.. Free Press of Glencoe.

2. M.B. Clinard, Anomie and Deviant Behaviour, 1964, Free Press of Glencoe.

3. E. Durkheim, Suicide, trans. J.A. Spaulding and G. Simpson, 1952, London: Routledge and Kegan Paul, p. 246.

4. Merton, op. cit., pp. 132-4.

5. A.wk. Cohen, Delinquent Boys: The Culture of the Gang, 1956, London: Routledge and Kegan Paul.

6. R. A. Cloward and L.E. Ohlin, Delinquency and Opportunity: A Theory of Delinquent Gangs, 1963, London: Routledge and Kegan Paul.

7. J.P. Gibbs and W.T. Martin, Status Integration and Suicide, 1964, University of Oregon Press.

8. Durkheim, op. cit., pp. 373-4.

9. Gibbs and Martin, op. cit.

10. Durkheim, op. cit., p. 382 .

11. J. L. Horowitz, "On alienation and the Social Order," Philosophy and Phenomenological Research, 1966, 27, 230-237.

12. Marx, quoted by E. Fromm, Marx's Concept of Man, 1963, New York: Frederick Ungar. 
13. K. R. Popper, The Open Society and Its Enemies, Vol. II, 1957, London: Routledge, Chapter 22.

14. R. Blauner, Alienation and Freedom, 1964, University of Chicago Press, p. vii.

15. J. Horton, "The Dehumanization of Anomie and Alienation: A Problem in the Ideology of Sociology," British Journal of Sociology, 1964 , 15, 283-300.

16. Aristotle, Politics, Book I, trans. W. Ellis, 1912, London: Dent, pp. 4-5.

17. H. Alpert, "Emile Durkheim: Enemy of Fixed Psychological Elements," American Journal of Sociology, 1958, 63, 622-664.

18. Clinard, op. cit., p. 37 .

19. T. Parsons, R.F. Bales, and E. A. Shils, Working Papers in the Theory of Action, 1953, Free Press of Glencoe, pp. 67-8.

20. G. Nettler, "A Measure of Alienation," American Sociological Review, $1957,22,670-677$.

21. E. H. Mizruchi, Success and Opportunity, 1964, Free Press of Glencoe, p. 5 .

22. Horton, op. cit., p. 289.

23. Ibid., p. 285 .

24. B. Dohrewend, "Egoism, Altruism, Anomie and Fatalism: A Conceptual Analysis of Durkheim's Types," American Sociological Review, 1959, 24, 466-473.

25. T. Parsons, "Some Reflections on the Place of Force in Social Process," in H. Eckstein, ed., Internal War, 1964, Free Press of Glencoe, pp. $33-70$.

26. Gibbs and Martin, op. cit.

27. B. D. Johnson, "Durkheim's One Cause of Suicide," American Sociological Review, 1965, 30, 875-886. Cí. M. Halbwachs, Les Causes du Suicide, Paris, 1930, who used a single variable to account for suicide, that of "social isolation."

28. Aristotle, Ethics, Book 7, trans. J. A. K. Thompson, London: Penguin Books, 1953.

29. C. Bagley, "Juvenile Delinquency in Exeter: An Ecological and Comparative Study," Urban Studies, 1965, 2, 33-50. 
30. Cohen and Cloward and Ohlin, op. cit.

31. D. M. Downes, Delinquent Subcultures in East London, $\mathrm{Ph}$.D. Thesis, London University, 1964, p. 464, Cf. G. L. Mosse on fascism as a barbaric remedy to alienation. ("The Genesis of Fascism," Journal of Contemporary History, 1965, 1, 14-26).

32. W. F. Whyte, The Organization Man, New York: Doubleday Anchor Books, 1957, p. 184 (quoted by Mizruchi, op. cit., p. 4).

33. Durkheim, op. cit.

34. A. Gouldner, ed., Durkheim's Socialism, 1962, New York: Collier Books, editor's introduction, p. $2 i$. 